\title{
The Exercise Model of Shooting Skills for the Beginner Players Women's of Futsal
}

\author{
Ahmad Rizal ${ }^{1}$, Hernawan ${ }^{2}$, Iman Sulaiman ${ }^{3}$ \\ ${ }^{1,2,3}$ Postgraduate Sports Education, State University of Jakarta, Indonesia \\ rizalahmad8393@gmail.com
}

\begin{abstract}
The aim of this study is to develop a shooting skill exercise model design for beginner players women's of futsal to obtain empirical data about the effectiveness of the results of shooting skill exercise models for beginner players women's of futsal. The method used in this study is the research and development method of Borg and Gall which consists of ten steps. The subject of this research is a beginner woman futsal player. The final results of this study are model manuals and shooting skills exercise video models for woman futsal players with a final model number of 27 models that have gone through expert evaluation, trial and revision, and effectiveness has been tested. The effectiveness of the application of shooting skills exercise models for woman futsal beginners uses the "t-test" technique. $p$ data on the results of the pretest and posttest shooting skill training for beginner woman futsal players with a significance level of 0.05 . The results of shooting skills training for woman futsal beginner players between pretest is 2.0645 with posttest of 2.9294 (at a significance level of 0.05), then it shows that the results of the increase in the post-test group are higher than the pre-test group. Thus it can be stated that, the shooting skill exercise model for beginner woman futsal players is effectively used to improve the results of shooting skills beginner woman futsal players. Thus it can be stated that, the shooting skill training model for beginner woman futsal players is effectively used to improve the results of shooting skills.
\end{abstract}

Keywords : Exercise model; shooting skills; futsal.

\section{Introduction}

The development of women's soccer or futsal is even higher. The limited open field encourages futsal as an alternative to channel the abilities of woman futsal players. The problem that arises in a beginner woman futsal players is in mastering basic futsal technique skills. Shooting is a basic technique for woman futsal players that is difficult to do among other techniques. This is caused by the implementation of good and correct shooting according to the target towards the goal and requires strength in its implementation. The size of a field that is not as wide as football allows for continuous movement.

Currently there are a lot of the competitions inter the women's futsal club, both beginner and professional level. The initial observation was carried out during the trial with one of the clubs in the Depok area, the AFK Depok club where the club has 40 beginner players who have just joined for 3 months in 2019. At the beginner level the mastering of basic technical skills is very important for players, by therefore the more events carried out in various regions or even competitions conducted between clubs the more observations made. The importance of shooting kicks in futsal, it is necessary to increase the accuracy of shooting kicks in order to perfect the skills possessed by woman futsal players. The thing that is often seen is when the woman futsal team players during the trial and competition in the event, the players are very difficult to do shooting techniques where the opportunity and opportunity did not make the decision to do the shooting technique. The aspects that are owned by players can not only be done but also must be trained in its implementation, this is a reference because the processes that occur in a match cannot be determined. 
Noting the conditions above, it can be stated that the main cause of these symptoms is located in the use of irrelevant exercise models. The exercise model that has been used is not in accordance with the characteristics of woman futsal players and teaching materials. Therefore, the exercise model is needed to be able to improve the mastery ability of basic techniques to shoot the ball in competition so that it can have an impact on understanding and increasing the stages of shooting motion in futsal games.

\section{Review of Literatures}

\section{The Concept of Model Development}

Development of a learning model is one form of the application of a system approach in learning activities based on a systematic process in learning activities that produces a learning system that is ready to be used appropriately. Models can be used to organize various sources then used as a stimulus to develop hypotheses and construct theories into concrete terms / conditions to apply them to practice or test theories. Based on the opinions above, then in this research and development what is meant by the model is a pattern of steps which includes analysis, development, material production and evaluation in order to facilitate the achievement of goals. Research has a variety of types. There are the type of research is based on research goals, research methods, and the field of study discussed (Tangkudung, 2016: 5). In the world of education research methods that are widely used include experimental methods, qualitative research, surveys and development $(\mathrm{R} \& \mathrm{D})$.

$\mathrm{R} \& \mathrm{D}$ research has a variety of models that can be used. The researchers chose by adjusting the needs and suitability of the research development. Some models of R \& D research such as (1) Dick and Carey's development model (2) ADDIE development model, (3) Borg and Gal development model, (4) device development model according to J. E. Kemp, (5). 4-D development model. (6) ASSURE development model. In this study we will use the Borg \& Gall development model where the development model guides the researcher step by step in detail and the task analysis described by Borg \& Gall is arranged in detail and the specific objectives clearly, and the repeated trials can produce results reliable system. However, the weakness of this model is that the trial is not clearly explained when it must be done and the revision activities will be carried out after the test is held.

\section{The Concept of Developed Model}

The development of futsal shooting exercise models is expected to be a product that can be developed systematically and logically, so that this product has the effectiveness that is feasible to use. Futsal in its development is increasingly popular among women. Shooting which is one of the basic techniques that is important because a smaller size futsal court creates the possibility of more shooting on goal. This shooting technique is not only owned by one player position but all playing positions in futsal must have a good shooting technique to help the process of creating a goal.

Based on the description of the background, the formulation of the problem and an explanation of the five models developed, selected the most appropriate model for the implementation of the research and development made. The model of research and development implemented is the development model of Borg \& Gall. This research has relevance with Borg \& Gall because the steps are in line with the objectives of the research and development carried out. Borg \& Gall's steps are in line with the objectives of research and 
development, by applying sequential steps starting from analyzing needs, designing products, developing products, implementing products and evaluating them.

\section{Exercise}

The process of exercise is the basis of increasing physical effectiveness. Exercise is the main element in improving all aspects of the body, so we must understand what real exercise means. This is reinforced by the statement by Rygula and Cholewa "Taking this into consideration sport scientists must seek more adequate mathematical and numerical methods for solving the complex problems of sports training" (Cholewa, Czuba, \& Zajac, 2009: 263) This is so that sports scientists must look for mathematical and numerical methods that are more appropriate in solving complex sports training problems. At beginner players the process of exercise in sports must be planned in an appropriate training program especially in planning between multilateral and special sports specialization.

\section{Futsal}

Futsal is a means to develop the talents of soccer players. The player can master the game techniques, such as herding, kicking, heading, passing, holding and attacking. The word futsal itself means indoor football. The word futsal comes from the word "fut" taken from the word futbol or futebol, which in Spanish and Portugal means football. And "sal" is taken from the word sala or salao which means indoors. (Eka, Darmawan, \& Ganesha, 2014: 1). Futsal is played 5 to 5 in a room which is currently able to be utilized properly because it does not require a wide field like soccer. It can be found everywhere in the futsal field or even in every housing we live in there is an area playing futsal. This has led to progress and increased public interest in this sport.

\section{Shooting Skills}

With a small field size and a smaller number of players allows frequent kicks towards the goal or shooting balls. Shooting is a basic technique that must be mastered by every player, this technique is a way to create goals, because all players have the opportunity to score in winning the competition. (Andri Irawan, 2009: 33) This statement was reinforced by Rajidin who said that shooting is a combination and understanding of players when shooting that must be considered and given exercise, because this is an important component for a player to be able to score goals in every situation or momentum in games and competition where there is an opportunity to maximize abilities or opportunities in it. (Rajidin, 2014: 2) Players who have good kicking techniques will be able to play efficiently. The aim of kicking a ball is to pass (shooting), shoot at the goal (shooting at the goal), and sweep or distance the ball from the goal itself and sweep to thwart the opponent's attack (sweeping).

This is also supported by the theory presented by Widiastuti (2015: 233) which states that the movement of skills is that it can be done through the learning process (Rahmansyah, Jufrianis, Tangkudung, 2018: 63) Motion skills are movements that follow a certain pattern or form that requires coordination or control of part or all of the body that can be done through the learning process. The ability to move in shooting must be done effectively and efficiently. Shooting skills can also be said as manipulative movements because they are done using the feet. It aims to be able to score goals in opponents and become the main goal in a futsal game. 


\section{Beginner Characteristics}

When entering the teenage phase or beginner an individual person has started doing sports activities on his own encouragement for his needs. At this time it is also the right time for individuals to pursue achievements in the field of sports in accordance with the characteristics and abilities of mastered sports. This period is a period of searching for an individual's identity to be able to show and demonstrate his abilities, especially in the field of sports with full confidence. Rumini defines adolescence as covering a period of time from the end of the child's age to the age of adulthood, by dividing: early adulthood and late adulthood, so susceptible adolescents include 11 or 12 years to 21 years. (Rumini, 2006)

Adolescence is a period that has an important phase in optimizing talent and abilities in individual development. During this time the child has experienced many changes both physically and hormonally. The same is related to the characteristics of adolescents expressed by Ozdemir, Utkualp, and Pallos stating that:

"The terms adolescence means growing mature by developing and refers to the transition period from childhood to adulthood. This period is dynamic process in which a rapid physical, biochemical, psychological, and social growth, development, and maturation take place." (Ozdemir, Utkualp, \& Pallos, 2016:719)

The term teenager means to grow and develop, starting from children to adults. At this time the process through is dynamic, where the growth and development of physical, biochemical, psychological and social maturation that occurs takes place so fast. Generally, during this time adolescents adjust to the best possible. Therefore this exercise in young beginners refers to the development of fundamental movement skills or often called basic motion abilities. This needs to be done as a foundation for beginners to get the highest achievement at the peak age of each sport. The training given is more focused on the exercise of flexibility, speed, and patience that is manipulated with fun activities.

\section{Model Design}

A model in development research is presented in the part of the development procedure, which usually follows the development model adopted by the researcher. The model can also provide a framework for theory and research development. By following a particular model adopted by the researcher, a number of inputs will be obtained to make improvements to the products produced, whether in the form of teaching materials, media, or other products. From the models described above, in the research this will use the Borg and Gall development model where the development model guides researchers step by step in detail, and this model also allows learning groups to be actively interacting because it sets out strategies and types of learning that are environmentally based. The analysis of the tasks described in the Borg and Gall models is arranged in detail and hierarchical special learning goals and repeated trials can provide reliable system results.

Thus development research can be concluded as research that produces a product that has been analyzed in advance the level of effectiveness in learning, and has been designed, evaluated, and revised with the results of the development of the model. In this case what will be developed is the development of a shooting skill training model for beginner players women's of futsal. 


\section{Research Methods}

Development research aims to produce new products that can be used by educators in facilitating the learning process and the goals to be achieved can be in accordance with what is expected.

The aim of the research and development of this training model is for woman futsal beginners, among others (1) Developing a shooting skills training model for woman futsal beginners; (2) Improve shooting exercise skills for beginner players women's of futsal.

\section{The Characteristics of Models Developed}

Planning and drafting are made so that they can bind instructions and clear guidance in conducting research later in the exercise, planning and preparation of training models are factors that determine the success of a program. In connection with that, the development of shooting skills exercise models that will be compiled and developed in the form of modification and creativity in the form of training. In the world of futsal exercise analysis is expected to provide answers on what is the needs of woman futsal players at this time, so that training can be obtained that is effective, efficient and has attractiveness in the exercise process. Especially for beginners, woman futsal players who have just known futsal or amateur levels for competition. In general, beginner players have doubts in doing kick shooting techniques because they do not know how to do the right technique. The shooting training model provided by the trainer must be varied so that the players, especially beginner players, do not have boredom.

\section{Expert Judgment}

Expert judgment was conducted by three experts, consisting of futsal experts (lecturers), futsal experts (trainers), and woman futsal experts (lecturers). The validation was carried out on the results of the draft in the form of writing and drawing. If there is a revision, it will be made, and if there are no revisions, it will be continued to the field directly by small groups. For the purpose of a statement or recommendation, the researcher prepared a certificate format "Expert recommendation" which was later signed by experts as proof that the exercise model of shooting skills for beginner players women's of futsal was validated.

\section{Data analysis}

Data collected during needs analysis, expert validation: small group trials, large in the form of qualitative data, as well as observations and suggestions as well as qualitative data in the form of questionnaire results and also well documented effectiveness test results and then used as material to determine the effectiveness model of exercise model of Shooting skill for beginner players women's of futsal developed. Data on the results of the pre-test and post-test exercise model of shooting skills for beginner players women's of futsal of the experimental group and the control group were analyzed by t-test (Sugiyono, 2008).

Table 3.2 Research Design in Model Effectiveness Test

\begin{tabular}{cccc} 
Subject & Pre-Test & Treatment & Post-Test \\
\hline R & $\mathrm{O}_{1}$ & $\mathbf{P}$ & $\mathrm{O}_{2}$ \\
\hline
\end{tabular}


The research hypothesis on the effectiveness of the model developed is that it is thought that there is a significant effect on the application of the exercise model of shooting skill for beginner players women's of futsal. The steps taken in the trial include; (1) determine the research subject group; (2) carry out the pre-test $\left(\mathrm{O}_{1}\right)$; (3) provide treatment of the model that has been developed; (4) do post-test $\left(\mathrm{O}_{2}\right)$; (5) looking for the average score of the pre-test and post-test then compared between the two; (6) look for the difference in the second difference on average through the statistical method (t-test) to determine whether there is a significant effect of the use of the developed model. The formula for processing the overall data of the trial subjects using the t-test procedure and using the SPSS application.

\section{Research Results and Discussion}

In general, the results of this study include (1) the exercise model of shooting skill for beginner players women's of futsal, (2) Guidebook for the exercise model of shooting skill for beginner players women's of futsal. The exercise model of shooting skill for beginner player women's of futsal was held at the Princess Futsal Club in DKI Jakarta, South Tangerang using the development method of Borg and Gall.

Based on data that can be collected from exercise experts of training methods, futsal experts and data during small group trials and field trials from participants, then there are several parts of the product that need to be revised. This is done to further optimize the benefits of developing the exercise model of shooting skill for beginner players women's of futsal.

Table 2. Results of Shooting Exercises Group Statistics

\begin{tabular}{|cc|c|c|c|c|}
\hline & Class & N & Mean & Std. Deviation & Std. Error Mean \\
\hline SHOOTING & PRETEST & 62 & 2.0645 & .80716 & .10251 \\
RESULTS & POSTTEST & 62 & 2.9194 & .94606 & .12015 \\
\hline
\end{tabular}

Looking at the data above the results of the Pre-test are 2.0645 and the results of the post-test are 2.9194 (in the table statistics). From these data it can be seen that the score of the post-test class is higher or greater than the pre-test group. This difference is strengthened by a significant score that is smaller than $0.05(5 \%)$, which is 0,000 (in the Independent Samples Test table, Sig 2 tailed column).

Table 3. Summary of the Effectiveness Test Results of the Exercise Model of Shooting with the t-Test

Independent Samples Test

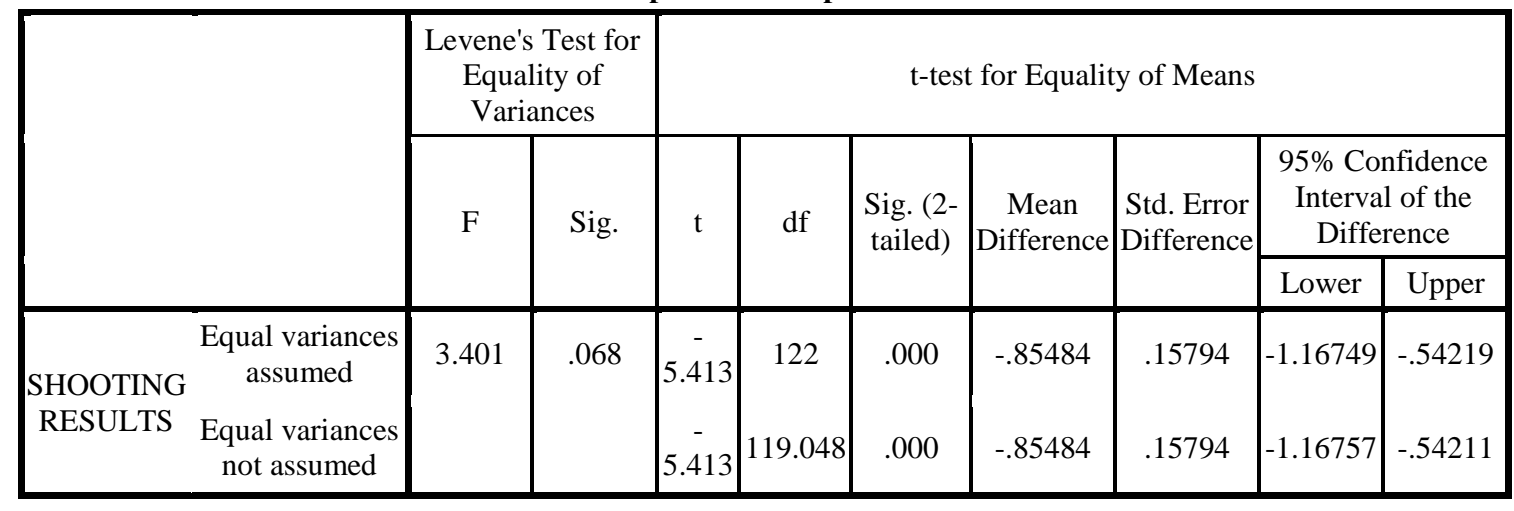


Based on the above calculation results obtained a Sig 2 tailed score of $0,000<0,005$, then there is a difference between the mean of the class post-test with an average score of 2,9194 with the average group pre-test class with a score of 2,0645. This shows that the results of the increase in the post-test class group were higher than the pre-test group. Thus it can be stated that, the exercise model of shooting skill for beginner players women's of futsal is effectively used to improve the results of shooting skills for woman futsal players.

\section{Conclusion}

From the results of field trials and discussion of the study it can be concluded that (1) Based on the results of evaluation expert and trials that have been carried out obtained the final model or final shooting skills exercise includes 27 exercise skills of shooting models for woman futsal players. (2) Based on the results of validation expert and trial, a product of exercise model of shooting skill has been produced for beginner woman futsal players in the futsal club which as a whole is worthy of being used by woman beginners.

This is based on the discussion of the results of the product trial analysis, which includes the factors of easiness, attractiveness, usefulness and safetiness and there are results from group trials, namely: (1) The size of the field so that it increases the exercise of shooting skills. (2) The time to exercised the shooting skills is accelerated so that players are more active in moving, (3) In giving instructions it must be clarified, (4) In carrying out the exercise carried out in how many repetitions to be clarified, (5) Number of players in the game.

Based on the results of the model effectiveness test, it is proven empirically that the product results in the form of the exercise model of shooting skill for beginner players women's of futsal have good effectiveness. It is based on the results of the shooting skills test which shows that the average posttest results are 2.9194 and in the pretest 2.0645 shows that the post test results are greater than the average results of the pretest. So that it can be stated that the exercise model of shooting skill for beginner players women's of futsal is effectively used to improve the results of shooting skills exercise with a significance score below 0.05 .

\section{Suggestion}

Based on the results of developing the exercise model of shooting skill for beginner player women's of futsal, it is necessary to put forward some suggestions by researchers regarding the products produced. The suggestions put forward include suggestions for use, suggestions for dissemination, and suggestions for further development.

\section{Suggestion for Use}

This development product is the development of the exercise model of shooting skill for beginner player women's of futsal. If the model of the exercise model of shooting skill for beginner player women's of futsal can be utilized in the futsal club, it can also be used for extracurricular activities and as an ingredient in learning in each school.

\section{Dissemination Suggestions}

The product of the development of the exercise model of shooting skill for beginner player women's of futsal in the form of this guidebook proved to have good effectiveness to improve shooting skills, so the product of this development can be disseminated to a broader 
target, especially to woman futsal club coaches or extracurricular trainer futsal. However, before it was disseminated, the researchers gave suggestion, so that the shooting skill model guide book for these new woman futsal players needed to be produced, so that later more woman futsal trainers could understand as training or learning material.

\section{Suggestions for Further Development}

In developing the product of the exercise model of shooting skill for beginner player of futsal in further woman futsal games, the researchers has several suggestions, namely: (a) the product development of the exercise model of shooting skill for beginner player women's of futsal still requires intensive and continuous study and testing and applied to a wider scope that has more diverse characteristics (heterogeneous), to obtain feedback to make product improvements; (b) Subjects involved in evaluation and trial activities need to be further expanded by involving more experts or physical condition exercise as well as instructors or trainers as users and players as subjects; (c) It is necessary to conduct an assessment in the next development on the level of variation and conformity with the age level. It is hoped that the model will be more varied, innovative, and stimulate players to be more enthusiastic in participating in the training. Shooting skills for beginner player women's of futsal.

\section{References}

Athirah, N., Rahman, A., \& Shaharudin, S. (2018). Comparison Of Skills And Lower Limb Biomechanics Of Woman Futsal Players At Collegiate And Club Levels, 7(2), 177-194.

Azi Faiz Ridlo. Lecture of PJKR FKIP in Islamic University "45” Bekasi 213, 213-225.

Bompa, O, Tudor., Haff, G. Gregory. (2009). Periodization. Theory and Methodology of Training. Fifth Edition.

Cholewa, J., Czuba, M., \& Zajac, A. (2009). The Effectiveness Of Chosen Training Means In The Development, IV(Iii), 262-271. https://doi.org/10.4100/jhse

Dora, B., Pembelajaran, D., Kelas, P., Sd, V. I., Palebon, N., ... Rustiadi, T. (2015). Journal of Physical Education, Sport, Health and Recreations, 4(7), 1957-1962.

Education, P. (2017). Effectiveness Of Shooting Training Model Febi Futsal Games On The Improvement $\mathrm{OF}, 321-326$.

Edwards, William, H. (2010). Motor Learning and Control. From Theory to Practice. California, USA: Wadsworth, Cengage Learning. Publisher: Yolanda Cossio.

Eka, G., Darmawan, B., \& Ganesha, U. P. (2014). Metode Pelatihan Taktis Passing Berpasangan Statis Dan Passing Sambil Bergerak Terhadap Keterampilan Teknik Dasar Passing Control Bola Futsal. Artikel, 1(2).

Fufu, O., Satriyasa, B. K., Tirtayasa, K., Made, L., Sri, I., Adiputra, H., ... Berubah, S. S. (2017). Pelatihan Shooting Dengan Sasaran Tetap Lebih Efektif Dari Pada Pelatihan Shooting Sasaran Berubah, 5(2), 103-113.

Gall, M. D., Gall, J. P., \& Borg, W. R. (2003). Educational Research (Seventh edition). Educational Research: An Introduction. http://psycnet.apa.org/psycinfo/1996-97171$\underline{000}$.

Gall, M. D., Gall, J. P., \& Borg, W. R. (2003). Educational Research (Seventh edition). Educational Research: An Introduction.

Gall, M, D., Gall, J. P., \& Borg, W. R. (1983). Educational Research an Introduction; Third Edition. USA: Pearson Education, 3(1):12-811. 
Budapest International Research and Critics in Linguistics and Education (BirLE) Journal

Volume 2, No 3, August 2019, Page: 472-480

e-ISSN: 2655-1470 (Online), p-ISSN: 2655-2647 (Print)

www.bircu-journal.com/index.php/birle

emails: birle.journal@gmail.com

birle.journal.qa@gmail.com

Göksu, I. (2014). Content Analysis of Research Trends in Instructional Design Models : 1999 - 2014, 10(2), 1999-2014.

Harsono. (2017). Kepelatihan Olahraga. Teori dan Metodologi. Bandung: PT. Remaja Rosdakarya.

Hermans, V., \& Engler, R. (2011). Futsal. Technique Tactics Training. UK: Meyer and Meyer Sport.

Irawan, Andri. (2009). Teknik Dasar Modern Futsal. Jakarta: PT. Pena Pundi Aksara.

Kemp, J. E., \& Ross, S. M. (2000). Designing Effective Instruction. Second Edition.

Lhaksana, Justinus., Pardosi, Ishak, H. (2008). Inspirasi dan Spirit Futsal. Jakarta: Raih Asa Sukses.

Milanovic, Z., Sporis, Goran., Trajkovic, N., Fiorentini, F. (2011). Differences In Agility Performance Between Futsal And Soccer ... Sport Science 4 ( 2011 ) 2 : 55-59

Munwaroh, I. (2016). Urgensi Penelitian dan Pengembangan. Universitas Negri Yogyakarta,15.

https://doi.org/http://staff.uny.ac.id/sites/default/files/PENELITIAN\%20PENGEMBAN GAN.pdf

Passerini, K., \& Granger, M. J. (2017). A developmental model for distance learning using the Internet, 1315(January 2000). https://doi.org/10.1016/S0360-1315(99)00024-X

Pribadi, A. Benny. 2009. Langkah Penting Merancang Kegiatan Pembelajaran Yang Efektif Dan Berkualitas. Jakarta: PT. Dian Rakyat

Puriana. (2017). Pengaruh Pelatihan Ladder Drill Hop 2017 Scotch Pattern Terhadap Kelincahan Pada Mahasiswa, (23).

Rajidin. (2003). Model Latihan Shooting Ke Gawang Pada Mahasiswa Ukm Sepak Bola IkipPgri Pontianak, (88), 192-201.

Rahmansyah, Beriman., Jufrianis., Tangkudung, James. (2018). The Effects Of Explosive Limb Muscle Strength, Eye-Foot Coordination And Self-Confidence In Shooting Skills, 4(2), 62-71.

Sasminta, Imam Hanafi., Hartati, Christina Yuli. Penerapan Modifikasi Permainan Terhadap Hasil Belajar Shooting Pada Permainan Futsal ( Studi Pada Peserta Ekstrakurikuler Futsal Smp Negeri 28 Surabaya) Abstract, 189-194.

Silalahi, A. (2018). Development research \& research and development. http://doi.org/10.13140/RG.2.2.13429.88803/1.

Smaldino, S. E., \& Lowther, D. L. (2010). Instructional Technology and Media for Learning, $1-22$

Soroka Andrzej. (2014). Trends in the gameplay of European football players.Baltic Journal Of Health And Physical Activity. Polandia: University of Physical Education and Sport in Gdansk, Vol. 6, No. 4, 2014, 267-272

Tangkudung, James. 2016. Macam-macam Metodologi Penelitian Uraian dan Contohnya. Jakarta: Lensa Media Pustaka Indonesia

Utomo, Eko Budi. (2017). Ketepatan Shooting Futsal ( Studi Pada Peserta Ekstrakulikuler Futsal SMP PGRI 7 Sedati tahun ajaran 2015 / 2016 ) Abstract, 07(3), 1-5.

Wahyu, Erfandi., Asmawi, M., Sulaiman, Iman. (2018). Model Latihan Keterampilan Shooting Futsal (DIYU) Untuk Anak SMA. Jurnal Penaskesrek, 5(2):190-197

Widiastuti. (2011). Tes dan Pengukuran Olahraga. Jakarta: Rajawali Press. 